\title{
ANALISIS SISTEM ANTRIAN DALAM PELAYANAN NASABAH PADA BANK BNI CABANG USU MEDAN
}

\author{
Oleh: \\ Drs. Sarimonang Sihombing, MBA
}

\begin{abstract}
PT Bank Negara Indonesia merupakan salah satu cabang BNI yang memiliki nasabah cukup banyak sehingga antrian nasabah merupakan pemandangan yang biasa setiap hari. Untuk memberikan pelayanan terhadap nasabah, pihak bank menyediakan 6 (enam) teller dengan jam kerja 8 jam setiap hari. Penelitian ini bertujuan, untuk memperkirakan jumlah petugas/teller yang bertugas melayani nasabah sehingga dapat memberikan pelayanan yang baik. Manfaat penelitian ini adalah untuk memberikan sumbang saran bagi PT. Bank Negara Indonesia (Persero) Tbk, Cabang USU Medan dalam hal memberikan pelayanan terhadap nasabah. Populasi dalam penelitian ini adalah seluruh nasabah yang antri untuk mendapatkan pelayanan dari teller. Sampel terdiri dari nasabah yang ingin mendapatkan pelayanan dari teller selama 20 (duapuluh) hari kerja, yaitu mulai tanggal 24 Oktober 2011 sampai dengan tanggal 25 November 2011 dengan 8 (delapan) jam kerja mulai pukul 08.00 - 16.00 WIB.

Analisis data dilakukan dengan dua cara yaitu secara kualitatif dan kuantitatif. Data dalam penelitian ini dianalisis dengan menggunakan perangkat lunak komputer yang disebut dengan quantitative method dengan modul waiting lines. Berdasarkan hasil pembahasan, pelayanan yang dilakukan Bank BNI dengan 6 (enam) teller pada waktu sibuk baik pukul 08.00 - 12.00 maupun pukul 12.00 - 16.00 belum optimal, rata-rata waktu tunggu nasabah antara 18,30 menit - 58,38 menit, sementara waktu tunggu yang dapat ditolerir nasabah adalah 15 menit. Pada waktu tidak sibuk dengan 6 (enam) teller, pelayanan sudah optimal dimana rata-rata waktu tunggu nasabah berada dalam batas toleransi. Saran dalam penelitian ini adalah, pada waktu sibuk baik pukul 08.00 - 12.00 maupun pukul 12.00 - 16.00, jumlah teller tambah menjadi 7 (tujuh) supaya pelayanan yang dilakukan sesuai harapan nasabah.
\end{abstract}

\section{PENDAHULUAN}

Persaingan yang semakin ketat seiring dengan tuntutan nasabah akan pelayanan yang lebih baik merupakan faktor pendorong adanya inovasi dan perubahan pada bisnis retail perbankan. Nasabah akan selalu memilih apa yang terbaik sesuai dengan keinginan mereka dalam hal pelayanan, yaitu pelayanan yang cepat dalam setiap melakukan transaksi perbankan. Kenyamanan dan kemudahan sudah menjadi tujuan, bahkan nasabah bersedia membayar lebih untuk mendapatkannya.

Untuk menghadapi tantangan persaingan dan tuntutan nasabah yang semakin kritis, lembaga perbankan berusaha meningkatkan pelayanannya. Masing-masing bank berusaha tampil sebaik mungkin agar dapat mempertahankan bahkan memperluas pangsa pasarnya. Sudah banyak bank besar yang mengawinkan keunggulan komparatifnya dengan melakukan merger atau akuisisi dalam rangka memperkuat daya saingnya.

Di pihak lain, masyarakat semakin kritis terutama jika mereka kecewa dengan pelayanan pihak bank. Masyarakat sering membanding-bandingkan pelayanan yang diberikan satu bank dengan bank yang lain, baik antar sesama bank pemerintah maupun dengan bank swasta. Kekecewaan yang dialami pelanggan, dampaknya bisa bermacam-macam. Salah satu diantaranya adalah dengan memindahkan rekening ke bank lain yang dianggap mampu memberikan pelayanan yang lebih baik. Hal tersebut tentunya merugikan pihak bank yang ditinggalkan karena mereka akan kehilangan nasabah. Dalam pemasaran, mencari pelanggan 
baru biayanya jauh lebih besar dibandingkan dengan mempertahankan pelanggan yang sudah ada. Oleh sebab itu, pihak bank harus mampu memberikan pelayanan yang sesuai dengan harapan pelanggan dalam rangka mempertahankan pelanggan yang sudah mereka miliki.

Pelayanan yang baik menurut pegawai bank kadang berbeda dengan pelayanan yang sesungguhnya diinginkan nasabah. Dalam kehidupan sehari-hari pegawai bank sendiri sering merubah arti layanan bermutu manakala mereka dalam posisi sebagai nasabah / pelanggan, misalnya ketika pegawai tersebut berada di asuransi atau rumah sakit. Ada beberapa hal yang menyebabkan bank kurang mendapat tempat di hati masyarakat, antara lain, letak dan lokasi tidak menarik, parkir tidak nyaman, ruang pelayanan tidak nyaman, antrian terlalu panjang, pelayanan lambat, petugas loket tidak ramah, dan sebagainya.

Dari uraian di atas dapat dilihat bahwa bank sebagai perusahaan jasa di bidang keuangan perlu memperhatikan pelayanan nasabah dan sarana yang mendukung pelayanan. Pihak bank harus berusaha sungguh-sungguh menangani persoalan-persoalan yang menimbulkan kekecewaan nasabah. Dengan kata lain, pihak bank harus mampu membaca apa yang ada di pikiran masyarakat tentang pelayanan yang baik, karena hal itu akan sangat membantu mereka dalam merancang pelayanan yang berkenan di hati nasabah.

Citra dan reputasi bank akan rusak jika suatu bank tidak mampu memberikan pelayanan kepada nasabah sebagaimana mestinya. Harus diakui bahwa biaya untuk memperbaiki pelayanan relatif besar. Di sisi lain, pelayanan yang buruk akan berdampak pemborosan biaya yang jauh lebih besar. Meningkatkan pelayanan akan menghasilkan keuntungan melalui peningkatan citra bank yang pada akhirnya meningkatkan kepercayaan masyarakat untuk menyimpan dananya ataupun meminjam. Perlu diketahui bahwa masyarakat yang sudah percaya dengan bank tertentu atau nasabah yang merasa puas atas pelayanan suatu bank menjadi kurang sensitif terhadap harga.

Peningkatan mutu pelayanan akan memberikan manfaat bagi bank dalam meningkatkan laba. Untuk itu bank perlu menyadari bahwa untuk mencapai hasil yang lebih harus dimulai dari perbaikan pelayanan kepada nasabah. Salah satu layanan terpenting di bank yang dapat memberikan image yang baik pada nasabah adalah melalui pelayanan yang diberikan oleh Front Office Bank khususnya dalam pencapaian sistem antrian nasabah.

Antri atau menunggu adalah hal yang paling dihindari oleh banyak orang. Pada bank BNI cabang Dr,Mansur, antrian nasabah merupakan pemandangan yang biasa setiap hari. Dengan jumlah teller sebanyak 6 orang dan customer service sebanyak 4 orang, antrian nasabah tetap tak terhindarkan karena banyaknya nasabah bank tersebut.

Untuk melihat peranan sistem antrian dalam perbaikan citra suatu bank, penulis memilih PT. Bank Negara Indonesia Cabang Dr. Mansur Medan sebagai objek penelitian, karena bank tersebut merupakan salah satu cabang Bank BNI di Medan yang mempunyai nasabah yang cukup banyak. Kecepatan pelayanan dan waktu tunggu yang tidak terlalu lama serta penentuan formasi yang tepat merupakan salah satu daya tarik tersendiri bagi nasabah dan cabang BNI Dr.Mansur sangat memerlukan hal tersebut untuk dapat mempertahankan keutuhan dan loyalitas nasabahnya. Untuk mendukung hal tersebut sangatlah dibutuhkan analisis yang tepat dalam penentuan formasi jumlah teller yang diperlukan.

\section{Perumusan Masalah}

Untuk dapat memberikan pelayanan yang baik, bank perlu menyediakan petugas yang sesuai dengan jumlah nasabah yang ada. Bank hendaknya dapat memperkirakan secara tepat jumlah pelayan / petugas sehingga tidak terjadi pemborosan tenaga dan biaya apabila ternyata jumlah pelayan / petugas terlalu banyak, atau sebaliknya, jika jumlah pelayan kurang akan 
mengakibatkan terjadinya antrian nasabah yang panjang sehingga harus menunggu untuk waktu yang relatif lama untuk mendapatkan pelayanan.

Dari uraian di atas, masalah dalam penelitian ini dirumuskan sebagai berikut: "Berapa banyak teller yang perlu disediakan, kapan perlu ditambah dan dikurangi untuk memberikan pelayanan yang optimal kepada nasabah".

\section{Karakteristik Antrian}

Setiap masalah antrian dapat diuraikan dalam tiga karakteristik (Schroeder, 1994) :

a. Kedatangan

Kedatangan digambarkan dengan statistik, yang dapat ditentukan dengan dua cara yaitu: kedatangan per satuan waktu atau distribusi waktu antar kedatangan. Jika distribusi kedatangan dicirikan dengan cara yang pertama jumlah kedatangan yang dapat terjadi dalam periode waktu tertentu harus dijelaskan. Cara kedua untuk menspesifikasikan kedatangan adalah waktu antar kedatangan. Dalam hal ini ditentukan distribusi probabilitas dari suatu variabel acak kontinu yang mengukur waktu dari satu kedatangan ke kedatangan berikutnya.

b. Antrian

Sifat dari antrian juga mempengaruhi tipe model antrian yang diformulasikan. Salah satu ketertiban antrian yang paling umum adalah aturan pertama datang pertama dilayani (firstcome-first-served). Aturan antrian yang lain adalah di mana satu kedatangan tertentu memiliki prioritas dan langsung ke urutan antrian terdepan. Bila menggambarkan antrian, panjang baris antrian juga harus ditentukan. Suatu asumsi matematis yang umum adalah bahwa baris antrian dapat mencapai suatu panjang yang tak terbatas (infinite-length).

Perilaku pelanggan dalam antrian juga harus didefinisikan. Berapa lama pelanggan akan menunggu layanan sebelum mereka meninggalkan antrian? Berapa pelanggan mungkin tidak akan bergabung dalam antrian jika mereka mengamati situasi yang padat ketika mereka datang. Perilaku pelanggan yang diasumsikan dalam model antrian sederhana adalah pelanggan akan menunggu hingga mereka dilayani. Untuk tujuan analisis, asumsi-asumsi antrian yang paling umum adalah aturan pertama dating pertama dilayani, panjang antrian tak terbatas, dan kedatangan menunggu hingga mendapat pelayanan.

a. Pelayanan

Beberapa karakteristik pelayanan yang masalah antrian adalah distribusi waktu pelayanan dan jumlah pelayan (yang melayani). Waktu pelayanan dapat bervariasi dari satu pelanggan ke pelanggan berikutnya. Asumsi waktu yang umum untuk distribusi waktu pelayanan adalah distribusi eksponensial, dalam hal ini waktu pelayanan akan bervariasi. Distribusi waktu pelayanan lain yang juga digunakan dalam masalah antrian adalah waktu pelayanan konstan, waktu pelayanan normal, dan waktu pelayanan seragam/uniform.

Karakteristik kedua dari pelayanan yang harus ditentukan adalah jumlah pelayan (yang melayani). Mungkin terdapat pelayan tunggal atau pelayan multi, tergantung kepada jumlah kapasitas yang dibutuhkan. Tiap-tiap pelayanan kadang-kadang disebut sebagai saluran (channel). Pelayanan dapat diberikan daam satu tahap di mana pelanggan harus melalui dua ataulebih pelayanan secara berurutan untuk menyelesaikannya. Kombiasi dari banyak pelayanan dan banyak tahap menimbulkan empat masalah antrian seperti ditunjukkan dalam gambar berikut: 


\section{Situasi Berbagai Antrian}

Satu saluran satu tahap

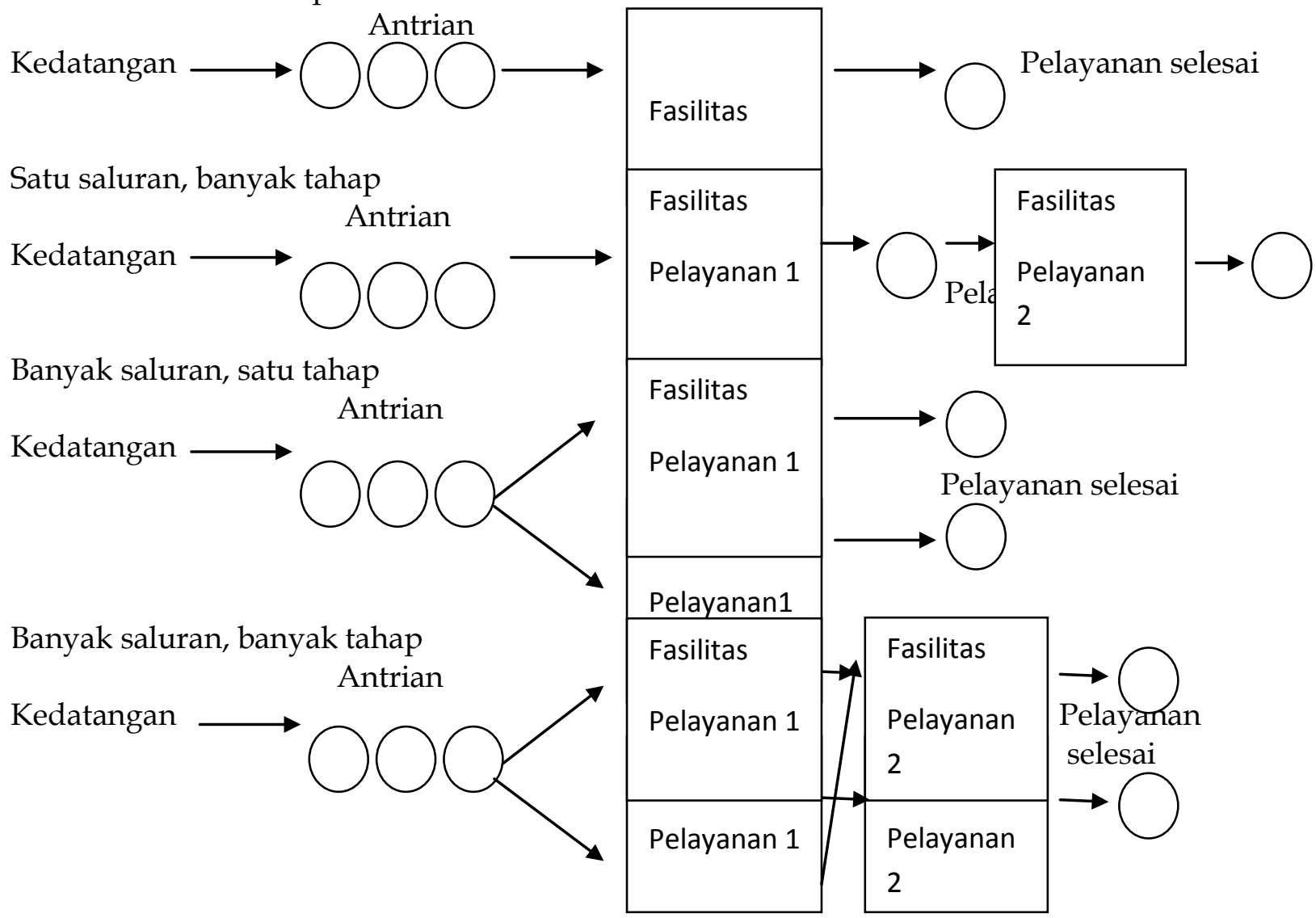

Sumber: Schroeder, Roger G. Manajemen Operasi, jilid 1. Terjemahan oleh tim penerjemah Erlangga Jakarta: Erlangga, 1997.

Menurut Levin dkk (1997), tiga bagian sistem antrian akan dijelaskan sebagai berikut:

1. Sifat pemanggilan populasi

Bagian dari sistem antrian ini mempunyai tiga sifat yang akan kita uraikan:

a. Besar kecilnya pemanggilan populasi

b. Sifat kedatangan dari pemanggilan populasi

c. Tingkah laku pemanggilan populasi

Besar kecilnya pemanggilan populasi. Pemanggilan populasi bisa tidak terbatas, bisa pula terbatas. Contoh sehari-hari pemanggilan populasi tidak terbatas antara lain adalah mobil yang tiba di gerbong tol, pasien yang datang ke kamar darurat. Contoh pemanggilan populasi terbatas adalah tiga perkakas tenun dalam pabrik pemintalan yang memerlukan pelayana operator secara terus menerus atau empat mobil dari sebuah perusahaan kecil yang mengunjungi fasilitas reparasi secara periodik.

Sifat kedatangan dari pemanggilan populasi. Elemen/subyek pemanggilan populasi bisa tiba pada fasilitas pelayanan dalam beberapa pola tertentu, bisa juga secara acak. Bila kedatagannya acak, kita harus tau probabilitasnya melalui waktu antara kedatangan. Analisis IM/OR telah mendapati bahwa kedatangan acak paling cocok diuraikan melalui distribusi Poisson. 
Tingkah Laku Pemanggilan Populasi. Pemanggilan populasi dan subyeknya mempunyai tingkah laku yang berbeda dalam memasuki deretan. Secara rutin kita terpaksa masuk ke pompa bensin meskipun pompa itu sagat ramai, dan kita akan mau menunggu dalam deretan selama beberapa jam untuk mendapatkan karcis pertunjukan yang sangat kita minati.

2. Sifat Antrian (Deretan Penungguan). Rentang antrian bisa diklasifikasikan terbatas dan tak terbatas. Rentang antrian terbatas biasanya disebabkan oleh keterbatasan ruangan, atau perilaku subyek pemanggilan populasi. Bila kita anggap rentang antrian dapat berkembang hingga tak terbatas, maka analisis IM/OR akan lebih mudah dilakukan.

3. Biaya Antrian. Dalam kasus antrian, para manajer operasi harus memahami pilihan (trade off) antara dua biaya yaitu biaya untuk menyediakan pelayanan yang baik dan biaya yang terjadi bila pelanggan atau mesin harus menunggu. Para manajer menginginkan antrian yang cukup pendek sehingga pelanggan tidak merasa kesal dan kemudian meninggalkan antrian tanpa membeli, atau membeli tetapi tidak pernah kembali lagi. Para manajer masih dapat mentoleransi adanya antrian, jika biaya antrian yang terjadi seimbang dengan biaya penghematan untuk menyediakan fasilitas pelayanan.

Ragam Model Antrian

Menurut Heizer (2006), ada empat model yang paling sering digunakan dalam model antrian di mana keempat model tersebut memiliki tiga karakteristik umum. Keempat model ini menggunakan asumsi: Kedatangan berdistribusi Poisson, Penggunaan aturan FIFO, Pelayanan satu tahap.

Keempat model antrian tersebut adalah sebagai berikut:

Model A: Model Jalur Antrian Tunggal dengan Kedatangan Berdistribusi Poisson dan Waktu Pelayanan Eksponensial.

Permasalahan antrian yang paling umum mencakup jalur antrian jalur tunggal atau satu stasiun pelayanan. Dalam situasi ini, kedatangan membentuk satu jalur tunggal untuk dilayanai oleh stasiun tunggal. Diasumsikan sistem berada dalam kondisi berikut:

a. Kedatangan dilayani atas dasar first-in, first-out (FIFO), dan setiap kedatangan menunggu untuk dilayani, terlepas dari panjang antrian.

b. Kedatangan tidak terikat pada kedatangan yang sebelumnya, hanya saja jumlah kedatangan rata-rata tidak berubah menurut waktu.

c. Kedatangan digambarkan dengan distribusi probabilitas Poisson dan dating dari sebuah populasi yang tidak terbatas.

d. Waktu pelayanan bervariasi dari satu pelanggan dengan pelanggan yang berikutnya dan tidak terikat satu sama lain, tetapi tingkat rata-rata waktu pelayanan diketahui.

e. Waktu pelayanan sesuai dengan distribusi probabilitas eksponensial negatif.

f. Tingkat pelayanan lebih cepat dari pada tingkat kedatangan.

Rumus antrian:

Model A: sistem sederhana dapat ditunjukkan sebagai berikut:

$\Lambda \quad=$ jumlah kedatangan rata-rata per satuan waktu

$\mu \quad=$ jumlah orang yang dilayani per satuan waktu

Ls $\quad=$ jumlah pelanggan rata-rata dalam sistem

$$
=\frac{\Lambda}{\mu-\Lambda}
$$

Ws = jumlah waktu rata-rata yang dihabiskan dalam sistem 


$$
\begin{aligned}
& 1 \\
& =\frac{1}{\mu-\kappa} \\
& \mathrm{Lq}=\text { jumlah unit rata-rata yang menunggu dalam antrian } \\
& \Lambda^{2} \\
& =\overline{\mu(\mu-\Lambda)} \\
& \mathrm{Wq}=\text { Waktu rata-rata yang dihabiskan untuk menunggu dalam } \\
& \text { Antrian } \\
& =\frac{\Lambda}{\mu(\mu-\Lambda)} \\
& \rho_{\kappa}=\text { faktor utilisasi sistem } \\
& =\bar{\mu} \\
& \text { Po = probabilitas terdapat } 0 \text { unit dalam sistem } \\
& =1-\stackrel{\Lambda}{-} \\
& \mu \\
& \mathrm{P} \mathrm{n}>\mathrm{k}=\text { probabilitas terdapat lebih dari sejumlah } \mathrm{k} \text { unit dalam sistem, } \\
& \text { di mana } n \text { adalah jumlah unit dalam sistem } \\
& =\left[\frac{\kappa}{\mu}\right]^{\mathrm{k}+1}
\end{aligned}
$$

Model B: Model Antrian Jalur Berganda

Pada model antrian jalur berganda, terdapat dua atau lebih jalur atau stasiun pelayanan yang tersedia untuk menangani pelanggan yang datang. Asumsi bahwa pelanggan yang menunggu pelayanan membentuk satu jalur dan akan dilayani pada stasiun pelayanan yang tersedia pertama kali pada saat itu. Bentuk antrian jalur berganda satu tahap masih banyak ditemukan pada sebagian besar bank saat ini: sebuah jalur umum dibuat, dan pelanggan yang ada di barisan terdepan yang pertama kali dilayani oleh kasir.

Persamaan antrian untuk model B , sistem jalur bergada dirumuskan sebagai berikut:

$\mathrm{M} \quad=$ jumlah jalur yang terbuka

$\kappa=$ jumlah kedatangan rata-rata per satuan waktu

$\mu \quad=$ jumlah rata-rata yang dilayani per satuan waktu pada setiap jalur Probabilitas terdapat 0 orang dalam sistem

1

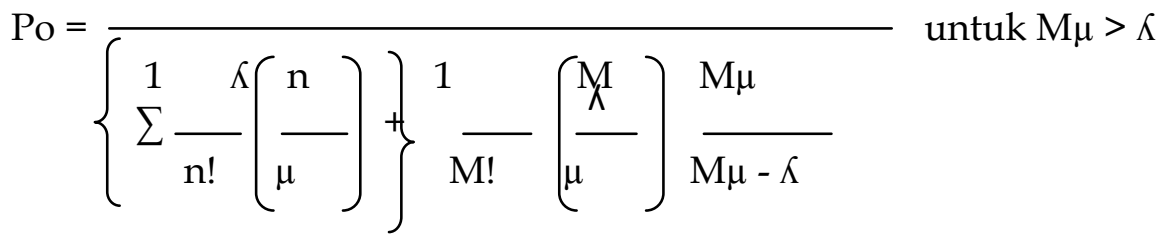

Jumlah pelanggan rata-rata dalam sistem: 


$$
\mathrm{Ls}=\frac{\Lambda \mu(\kappa / \mu)^{\mathrm{M}}}{(\mathrm{M}-1) !(\mathrm{M} \mu-\kappa)^{2}} \quad \mathrm{Po}+\frac{\kappa}{\mu}
$$

Waktu rata-rata yang dihabiskan seorang pelanggan dalam antrian atau sedang dilayani

$$
\mathrm{Ws}=\frac{\kappa \mu(\Lambda / \mu)^{\mathrm{M}}}{(\mathrm{M}-1) !(\mathrm{M} \mu-\kappa)^{2}} \operatorname{Po}+\frac{1}{\mu}=\frac{\text { Ls }}{\kappa}
$$

Jumlah orang atau unit rata-rata yang menunggu dalam antrian

$$
\mathrm{Lq}=\mathrm{Ls}-\frac{\kappa}{\mu}
$$

Waktu rata-rata yang dihabiskan oleh seorang pelanggan atau unit untuk menunggu dalam antrian

$\mathrm{Wq}=\mathrm{Ws}-1 / \mu-\mathrm{Ls} / \kappa$

\section{Model C: Model Waktu Pelayanan Konstan}

Beberapa sistem pelayanan memiliki waktu pelayanan yang tetap, da bukan berdistribusi eksponensial seperti biasanya. Di saat pelanggan diproses menurut sebuah siklus tertentu seperti pada kasus dari pencucian mobil otomatis atau wahana di taman hiburan, waktu pelayanan yang terjadi pada umumnya konstan. Oleh karena waktu yang konstan, maka nilai-nilai Lq, Wq, Ls, Ws selalu lebih kecil dari pada nilai-nilai tersebut pada model A, yang memiliki tingkat pelayanan bervariasi.

Rumus model pelayanan tetap adalah sebegei berikut

Panjang antrian rata-rata:

$$
\mathrm{Lq}=\frac{\Lambda^{2}}{2 \mu(\mu-\Lambda)}
$$

Waktu menunggu dalam antrian rata-rata:

$$
\mathrm{Wq}=\frac{\kappa}{2 \mu(\mu-\Lambda)}
$$

Jumlah pelanggan dalam sistem rata-rata:

$$
\mathrm{Ls}=\mathrm{Lq}+\frac{\kappa}{\mu}
$$

Waktu tunggu rata-rata dalam sistem:

$$
\mathrm{Ws}=\mathrm{Wq}+1 / \mu
$$

Model D: Model Populasi yang Terbatas

Ketika terdapat sebuah populasi pelanggan potensial yang terbatas bagi sebuah fasilitas pelayanan, maka model antrian berbeda harus dipertimbangkan. Model ini berbeda dengan ketiga model antrian sebelumnya, karena saat ini terdapat hubungan saling ketergantungan antara panjang antrian dan tingkat kedatangan.

Rumus dan notasi antrian untuk model D sebagai berikut:

Faktor pelayanan: $\mathrm{X}=$ 


$$
\mathrm{T}+\mathrm{U}
$$

Jumlah antrian rata-rata: $\mathrm{L}=\mathrm{N}(1-\mathrm{F})$

Waktu tunggu rata-rata: $W=\frac{\mathrm{L}(\mathrm{T}+\mathrm{U})}{\mathrm{N}-\mathrm{L}}=\frac{\mathrm{T}(1-\mathrm{F})}{\mathrm{XF}}$

Jumlah pelayanan rata-rata : $\mathrm{J}=\mathrm{NF}(1-\mathrm{X})$

Jumlah dalam pelayanan rata-rata : $\mathrm{H}=\mathrm{FNX}$

Jumlah populasi : $\mathrm{N}=\mathrm{J}+\mathrm{L}+\mathrm{H}$

Notasi: $\mathrm{F}=$ faktor efisiensi

$\mathrm{H}=$ rata-rata jumlah unit yang sedang dilayani

$\mathrm{J}=$ rata-rata jumlah unit tidak berada dalam antrian

$\mathrm{L}=$ rata-rata jumlah unit yang menunggu untuk dilayani

$\mathrm{M}=$ jumlah jalur pelayanan

$\mathrm{N}=$ jumlah pelanggan potensial

$\mathrm{T}=$ waktu pelayanan rata-rata

$\mathrm{U}=$ waktu rata-rata antara unit yang membutuhka pelayanan

$\mathrm{W}=$ waktu rata-rata sebuah unit menunggu dalam antrian

$\mathrm{X}=$ faktor pelayanan

\section{METODE ANALISIS}

Analisis data dilakukan dengan dua cara yaitu secara kualitatif dan kuantitatif. Data dalam penelitian ini dianalisis dengan menggunakan perangkat lunak komputer yang disebut dengan quantitative method dengan modul waiting lines.

\section{PEMBAHASAN}

Untuk mengetahui berapa lama sebenarnya waktu yang wajar menurut nasabah untuk menunggu hingga mendapatkan pelayanan dari teller Bank BNI Cabang USU, penulis melakukan wawancara terhadap enam puluh orang nasabah secara acak, dengan rincian tiga orang nasabah per hari selama duapuluh hari kerja. Wawancara dilakukan pada waktu sibuk ( akhir bulan, awal bulan, hari Senin dan Jumat sebagai awal dan akhir minggu) dan pada waktu tidak sibuk (hari Selasa, Rabu dan Kamis). Hasil tersebut diharapkan sudah dapat menggambarkan harapan nasabah secara keseluruhan dan untuk selanjutnya akan dibandingkan dengan waktu pelayanan yang sudah diberikan Bank BNI Cabang USU pada saat sekarang.

Dari hasil wawancara tersebut, penulis mengelompokkan jawaban nasabah mengenai waktu menunggu hingga dilayani menjadi dua bagian yaitu tanggal sibuk (tgl gajian, hari Senin sebagai awal minggu dan hari Jumat sebagai akhir minggu) dan tanggal tidak sibuk (hari Selasa, Rabu dan Kamis).

Data yang diperoleh dari hasil wawancara disajikan pada tabel berikut:

Tabel 1. Hasil Wawancara pada Waktu Sibuk

\begin{tabular}{|l|l|l|}
\hline Waktu Tunggu & Jumlah Nasabah & Persentase \\
\hline $5-15$ menit & 35 & $58,33 \%$ \\
\hline $15-25$ menit & 15 & $25 \%$ \\
\hline $25-30$ menit & 7 & $11,67 \%$ \\
\hline$>30$ menit & 3 & $5 \%$ \\
\hline
\end{tabular}




\begin{tabular}{|c|l|l|}
\hline Jumlah & 60 & $100 \%$ \\
\hline Sumber: Hasil wawancara pada waktu sibuk
\end{tabular}

Dari tabel di atas dapat dilihat hasil wawancara terhadap nasabah pada waktu sibuk, di mana yang mengatakan bahwa waktu tunggu yang wajar antara 5 sampai 15 menit sebanyak 35 orang atau $58,33 \%$ dari 60 orang. Terdapat 15 orang atau $25 \%$ yang mengatakan bahwa waktu tunggu yang wajar antara 15 - 25 menit, terdapat 7 orang atau 11,67\% yang mengatakan bahwa waktu tunggu yang wajar antara 25 - 30 menit dan terdapat 3 orang atau 5\% yang mengatakan bahwa waktu tunggu yang wajar adalah lebih dari 30 menit. Dengan demikian dapat disimpulkan bahwa waktu tunggu yang diharapkan nasabah hingga dilayani berkisar antara 5 -15 menit.

Hasil wawancara pada waktu tidak sibuk ditunjukkan pada tabel berikut:

Tabel 2. Hasil Wawancara pada Waktu tidak sibuk

\begin{tabular}{|l|l|l|}
\hline Waktu Tunggu & Jumlah Nasabah & Persentase \\
\hline $5-15$ menit & 38 & $63,33 \%$ \\
\hline $15-25$ menit & 16 & $26,67 \%$ \\
\hline $25-30$ menit & 5 & $8,33 \%$ \\
\hline$>30$ menit & 1 & $1,67 \%$ \\
\hline Jumlah & 60 & $100 \%$ \\
\hline
\end{tabular}

Sumber : Hasil wawancara pada waktu tidak sibuk

Dari tabel di atas dapat dilihat hasil wawancara terhadap nasabah pada waktu tidak sibuk, di mana yang mengatakan bahwa waktu tunggu yang wajar antara 5 sampai 15 menit sebanyak 38 orang atau $63,33 \%$ dari 60 orang. Terdapat 16 orang atau $26,67 \%$ yang mengatakan bahwa waktu tunggu yang wajar antara 15 - 25 menit, terdapat 5 orang atau 8,33\% yang mengatakan bahwa waktu tunggu yang wajar antara $25-30$ menit dan terdapat 1 orang atau $1,67 \%$ yang mengatakan bahwa waktu tunggu yang wajar adalah lebih dari 30 menit. Dengan demikian dapat disimpulkan bahwa waktu tunggu yang diharapkan nasabah hingga dilayani berkisar antara 5 - 15 menit.

Standar waktu menunggu yang ditetapkan oleh pihak Bank BNI Cabang USU adalah 15 menit, dengan harapan sudah sesuai dengan harapan nasabah. Kalau dibandingkan hasil wawancara yang dilakukan terhadap enampuluh nasabah selama dua puluh puluh hari kerja, waktu standar yang ditetapkan bank sudah sesuai. Tetapi apakah pelayanan yang dilakukan pihak bank dengan 6 teller dapat memenuhi standar yang ditetapkan akan dijelaskan pada pembahasan berikut.

Untuk mengetahui apakah pihak bank sudah mampu memberikan pelayanan sesuai harapan nasabah dengan enam teller, perlu diperhatikan variabel-variabel yang mempengaruhi sistem antrian. Pertama, rata-rata kedatangan nasabah per satuan waktu $(\Lambda)$. Kedua, rata-rata pelayanan per satuan waktu $(\mu)$. Ketiga, tingkat kesibukan atau penggunaan pelayan $(\rho)$. Nilainilai variabel ini akan ditampilkan setelah data-data terkait dengan antrian diolah dengan menggunakan modul waiting lines.

Data tentang antrian yang diperoleh dari Bank BNI Cabang USU selanjutnya akan diklassifikasikan menjadi dua bagian yaitu waktu sibuk (tanggal 27 - 31 Oktober , tanggal 1, 2, 3, 4, 7, 11, 18 November 2011), waktu tidak sibuk (tanggal 24-26 Oktober, tanggal 8, 9, 10, 14, 15, 16, 17 November 2011). Waktu pelayanan juga dibagi menjadi dua kelompok yaitu pukul 8.00 - 12.00 WIB dan pukul 12.00 - 16.00 WIB).

Tabel 3. Rata-Rata waktu teller melayani nasabah pada PT BNI Cabang USU Medan 
(dalam menit)

\begin{tabular}{|l|l|l|l|l|l|l|l|}
\hline No & Waktu & Teller 1 & Teller 2 & Teller 3 & Teller 4 & Teller 5 & Teller 6 \\
\hline 1 & $8.00-12.00$ & 4.32 & 5.02 & 4.31 & 4.40 & 4.06 & 4.29 \\
\hline 2 & $12.00-16.00$ & 4.20 & 4.28 & 4.15 & 4.26 & 4.10 & 4.25 \\
\hline \multicolumn{2}{|l|}{ Rata-Rata } & 4.26 & 4.65 & 4.23 & 4.33 & 4.08 & 4.27 \\
\hline
\end{tabular}

Sumber: Hasil pengamatan langsung terhadap 50 orang nasabah.

Dari tabel di atas dapat dilihat bahwa dari ke enam teller yang ada, teller 5 mempunyai waktu tingkat pelayanan rata-rata lebih cepat yaitu 4,08 menit jika dibandingkan dengan teller 1 (4,26 menit), teller 2 (4,65 menit), teller 3 (4,23 menit), teller 4 (4,33 menit) dan teller $6(4,27$ menit). Secara keseluruhan, rata-rata waktu yang dibutuhkan untuk melayani nasabah adalah 4,30 menit.

Tabel 4. Rata-rata jumlah nasabah yang antri pada PT BNI Cabang USU Medan, baik waktu sibuk maupun tidak sibuk dapat dilihat pada tabel berikut:

\begin{tabular}{|c|c|c|c|c|c|c|c|c|c|}
\hline \multirow[t]{3}{*}{ Tanggal } & \multicolumn{4}{|c|}{ Waktu Sibuk } & \multirow[t]{3}{*}{ Tanggal } & & & & \\
\hline & \multicolumn{2}{|c|}{$\begin{array}{l}\text { Jumlah Nasabah } \\
\text { Yang Datang }\end{array}$} & \multicolumn{2}{|c|}{ Jumlah nasabah } & & \multicolumn{2}{|c|}{$\begin{array}{l}\text { Jumlah Nasabah } \\
\text { Yang Datang }\end{array}$} & \multicolumn{2}{|c|}{ Jumlah nasabah } \\
\hline & $\begin{array}{l}08.00- \\
12.00\end{array}$ & $\begin{array}{l}12.00- \\
16.00\end{array}$ & Per hari & Per jam & & $\begin{array}{l}08.00- \\
12.00\end{array}$ & $\begin{array}{l}12.00- \\
16.00\end{array}$ & Per hari & Per jam \\
\hline $270 k t^{\prime} 11$ & 367 & 302 & 669 & 84 & 24Okt'11 & 321 & 318 & 639 & 80 \\
\hline 280kt'11 & 370 & 315 & 685 & 86 & 250kt'11 & 334 & 313 & 647 & 81 \\
\hline $310 k t^{\prime} 11$ & 401 & 260 & 661 & 83 & 260kt'11 & 349 & 302 & 651 & 81 \\
\hline 1Nov' 11 & 405 & 217 & 622 & 78 & 08Nov"11 & 338 & 329 & 667 & 83 \\
\hline 2Nov'11 & 417 & 323 & 740 & 93 & 09Nov'11 & 351 & 362 & 713 & 89 \\
\hline 3Nov'11 & 413 & 396 & 809 & 101 & 10Nov'11 & 326 & 316 & 642 & 80 \\
\hline 4Nov'11 & 410 & 382 & 792 & 99 & 14Nov'11 & 371 & 318 & 689 & 86 \\
\hline 7Nov'11 & 407 & 401 & 808 & 101 & 15Nov"11 & 380 & 296 & 676 & 85 \\
\hline 11Nov'11 & 435 & 421 & 856 & 107 & 16Nov'11 & 401 & 315 & 716 & 90 \\
\hline 18Nov'11 & 415 & 406 & 821 & 103 & 17Nov'11 & 389 & 371 & 760 & 95 \\
\hline Rata-Rata & 404 & 372 & 776 & 97 & Rata-Rata & 356 & 324 & 680 & 85 \\
\hline
\end{tabular}

Sumber: Hasil observasi pada Bank BNI Cabang USU

Dari tabel di atas dapat dilihat bahwa dalam satu jam terdapat rata-rata 91 orang nasabah yang menggunakan jasa Bank BNI Cabang USU. Perhitungan nilai $\Lambda, \mu$ dan $\rho$ dengan menggunakan modul waiting lines untuk dua kelompok waktu di atas ditunjukkan dalam tabel berikut:

Tabel 5. Waktu Pelayanan Pukul 8.00 - 12.00 WIB

\begin{tabular}{|l|c|c|c|c|c|c|}
\hline \multirow{2}{*}{ Keterangan } & \multicolumn{3}{|c|}{ Waktu Sibuk } & \multicolumn{3}{c|}{ Waktu Tidak Sibuk } \\
\cline { 2 - 7 } & $\mathrm{T}=6$ & $\mathrm{~T}=7$ & $\mathrm{~T}=8$ & $\mathrm{~T}=6$ & $\mathrm{~T}=7$ & $\mathrm{~T}=8$ \\
\hline Rata-rata Kedatangan $(\Lambda)$ & 101 & 101 & 101 & 89 & 89 & 89 \\
\hline Rata-rata Pelayanan $(\mu)$ & 17 & 17 & 17 & 16 & 16 & 16 \\
\hline Tingkat Pelayanan $(\rho)$ & 0,99 & 0,85 & 0,74 & 0,93 & 0,80 & 0,70 \\
\hline
\end{tabular}

Sumber: Hasil pengolahan data dari Bank BNI Cabang USU

Keterangan: Waktu sibuk (tgl 27 - 31 Oktober , tgl 1, 2, 3, 4, 7, 11, 18 November 2011), waktu tidak sibuk (tgl 24-26 Oktober, tgl 8, 9, 10, 14, 15, 16, 17 November 2011).

Dari Tabel 5 di atas dapat dilihat bahwa pada waktu sibuk pukul $08.00-12.00$, tingkat kesibukan pelayan $(\rho)$ dengan jumlah pelayan (Teller) $=6$ orang cukup tinggi yaitu mencapai 0,99 . Hal ini dapat diartikan bahwa teller sibuk melayani nasabah $99 \%$ dari total jam kerjanya per hari atau 7 jam 55 menit dari total jam kerja 8 jam. Apabila teller ditambah menjadi 7 orang, maka tingkat kesibukan teller $(\rho)$ turun menjadi 0,85 dan apabila teller ditambah menjadi 8 maka tingkat kesibukan teller $(\rho)$ turun menjadi 0,74 . 
Pada waktu tidak sibuk, tingkat kesibukan pelayan dengan 6 teller pukul $08.00-12.00$ adalah 0,93 , artinya pelayan sibuk melayani nasabah selama 93\% dari total jam kerjanya per hari yaitu 7 jam 26 menit dari total jam kerja 8 jam. Apabila teller ditambah menjadi 7 orang maka tingkat kesibukan teller $(\rho)$ turun menjadi 0,80 dan apabila teller ditambah menjadi 8 orang tingkat kesibukan teller $(\rho)$ turun menjadi 0,70 .

Dari uraian di atas dapat disimpulkan bahwa pada waktu sibuk jam $08.00-12.00$ pelayan terlalu sibuk apabila teller hanya 6 orang, dimana kalau pelayan terlalu sibuk dapat mengurangi kualitas pelayanan. Maka sebaiknya pada waktu tersebut jumlah pelayan ditambah menjadi 7 orang dengan tingkat pelayanan 0,85. Pada waktu tidak sibuk, dengan teller sebanyak 6 orang, tingkat penggunaan pelayan tetap tinggi yaitu 0,93. Apabila teller menjadi 7 tingkat penggunaan pelayan turun menjadi 0,80 dan apabila teller ditambah menjadi 8 tingkat penggunaan pelayan berkurang menjadi 0,70. Melihat tingkat penggunaan pelayan pada waktu tidak sibuk pukul 08.00 - 12.00 tetap tinggi, maka pada waktu tidak sibuk juga perlu ditambah jumlah teller menjadi 7 orang, dengan dengan tingkat penggunaan pelayan 0,80 .

Tabel 6. Waktu Pelayanan Pukul 12.00 - 16.00 WIB

\begin{tabular}{|l|c|c|c|c|c|c|}
\hline \multirow{2}{*}{ Keterangan } & \multicolumn{3}{|c|}{ Waktu Sibuk } & \multicolumn{3}{c|}{ Waktu Tidak Sibuk } \\
\cline { 2 - 7 } & $\mathrm{T}=6$ & $\mathrm{~T}=7$ & $\mathrm{~T}=8$ & $\mathrm{~T}=6$ & $\mathrm{~T}=7$ & $\mathrm{~T}=8$ \\
\hline Rata-rata Kedatangan $(\Lambda)$ & 93 & 93 & 93 & 81 & 81 & 81 \\
\hline Rata-rata Pelayanan $(\mu)$ & 16 & 16 & 16 & 16 & 16 & 16 \\
\hline Tingkat Pelayanan $(\rho)$ & 0,97 & 0,83 & 0,73 & 0,84 & 0,72 & 0,63 \\
\hline
\end{tabular}

Sumber: Hasil pengolahan data dari Bank BNI Cabang USU

Keterangan: Waktu sibuk (tgl 27 - 31 Oktober , $\operatorname{tgl} 1$, 2, 3, 4, 7, 11, 18 November 2011), waktu tidak sibuk (tgl 24-26 Oktober, $\operatorname{tgl} 8,9,10,14,15,16,17$ November 2011).

Dari Tabel 6 di atas dapat dilihat bahwa pada waktu sibuk pukul 12.00 - 16.00, tingkat kesibukan pelayan $(\rho)$ dengan jumlah pelayan (Teller) $=6$ orang cukup tinggi yaitu mencapai 0,97 . Hal ini dapat diartikan bahwa teller sibuk melayani nasabah $97 \%$ dari total jam kerjanya per hari atau 7 jam 46 menit dari total jam kerja 8 jam. Apabila teller ditambah menjadi 7 orang, maka tingkat kesibukan teller $(\rho)$ turun menjadi 0,83 dan apabila teller ditambah menjadi 8 maka tingkat kesibukan teller $(\rho)$ turun menjadi 0,73 . Melihat tingkat kesibukan pelayan yang sangat tinggi dengan teller sebanyak 6 orang, maka pada waktu sibuk pukul $12.00-16.00$ perlu ditambah menjadi 7 orang supaya dapat mempertahankan kualitas pelayanan.

Pada waktu tidak sibuk, tingkat kesibukan pelayan dengan 6 teller pukul $12.00-16.00$ adalah 0,84 , artinya pelayan sibuk melayani nasabah selama $84 \%$ dari total jam kerjanya per hari yaitu 6 jam 43 menit dari total jam kerja 8 jam. Apabila teller ditambah menjadi 7 orang maka tingkat kesibukan teller $(\rho)$ turun menjadi 0,71 dan apabila teller ditambah menjadi 8 orang tingkat kesibukan teller $(\rho)$ turun menjadi 0,63. Dari uraian di atas dapat disimpulkan bahwa pada waktu sibuk jam 12.00 - 16.00 tingkat kesibukan pelayan tetap tinggi yaitu antara $0,71-0,84$. Maka jumlah teller sebanyak 6 orang dapat dipertahankan.

Selanjutnya akan dihitung probabilitas tidak ada nasabah dalam sistem (Po), jumlah nasabah dalam antrian (Lq) dan jumlah nasabah dalam sistem (Ls). Hasil perhitungan dengan menggunakan Metode Waiting Lines, dapat dilihat pada tabel berikut.

Tabel 7. Nilai Po, Lq, Ls, Pukul 8.00 - 12.00 WIB

\begin{tabular}{|l|l|l|l|l|l|l|}
\hline \multirow{2}{*}{ Keterangan } & \multicolumn{3}{|c|}{ Waktu Sibuk } & \multicolumn{3}{c|}{ Waktu Tidak Sibuk } \\
\cline { 3 - 7 } & $\mathrm{T}=6$ & $\mathrm{~T}=7$ & $\mathrm{~T}=8$ & $\mathrm{~T}=6$ & $\mathrm{~T}=7$ & $\mathrm{~T}=8$ \\
\hline Probabilitas tidak ada & 0,00016 & 0,00173 & 0,0023 & 0,00143 & 0,00298 & 0,00353 \\
\hline
\end{tabular}




\begin{tabular}{|l|l|l|l|l|l|l|}
\hline nasabah (Po) & & & & & & \\
\hline $\begin{array}{l}\text { Jumlah nasabah dalam } \\
\text { antrian (Lq) }\end{array}$ & 98 & 3 & 1 & 11 & 2 & 1 \\
\hline $\begin{array}{l}\text { Jumlah nasabah dalam } \\
\text { sistem (Ls) }\end{array}$ & 104 & 10 & 7 & 16 & 8 & 7 \\
\hline
\end{tabular}

Sumber: Hasil pengolahan data dari Bank BNI Cabang USU

Keterangan: Waktu sibuk (tgl 27 - 31 Oktober , tgl 1, 2, 3, 4, 7, 11, 18 November 2011), waktu tidak sibuk (tgl 24-26 Oktober, $\operatorname{tgl} 8,9,10,14,15,16,17$ November 2011).

Dari Tabel 7 dapat dilihat bahwa dari pengamatan pada waktu sibuk pukul 08.00-12.00, dengan mempekerjakan 6 teller seperti selama ini dilakukan Bank BNI Cabang USU, diperoleh $\mathrm{Po}=0,00016$, dengan 7 teller $\mathrm{Po}_{\mathrm{o}}=0,00173$, dengan 8 teller $\mathrm{Po}_{\mathrm{o}}=0,0023$. Artinya, dengan 6 orang teller, probabilitas tidak ada nasabah baik dalam antrian maupun yang sedang dilayani adalah $0,016 \%$, dengan 7 orang teller naik menjadi $0,173 \%$ dan dengan 8 orang teller naik menjadi $0,23 \%$.

Pada waktu tidak sibuk pukul 08.00 - 12.00, dengan mempekerjakan 6 teller diperoleh $\mathrm{Po}=0,00143$, dengan 7 teller $\mathrm{Po}=0,00298$ dan dengan 8 teller $\mathrm{Po}=0,00353$. Artinya, dengan 6 teller probabilitas tidak ada nasabah baik dalam antrian maupun yang sedang dilayani adalah $0,143 \%$, dengan 7 orang teller naik menjadi $0,298 \%$ dan dengan 8 orang teller naik menjadi $0,143 \%$.

Dari Tabel 5.8 juga dapat dilihat rata-rata banyaknya nasabah yang terdapat dalam baris antrian $(\mathrm{Lq})$ pada waktu sibuk dengan 6 Teller pada pukul 08.00 - 12.00 adalah 98 orang, sedangkan kalau Teller ditambah menjadi 7 orang, rata-rata baris antrian hanya 3 orang dan kalau Teller ditambah menjadi 8 orang, rata-rata nasabah yang menunggu dalam antrian hanya 1 orang. Pada waktu tidak sibuk pukul 08.00 - 12.00 rata-rata banyaknya nasabah yang terdapat dalam baris antrian (Lq) dengan 6 Teller adalah 10 orang, sedangkan kalau Teller ditambah menjadi 7 orang, rata-rata baris antrian hanya 2 orang dan kalau Teller ditambah menjadi 8 orang, rata-rata nasabah yang menunggu dalam antrian hanya 1 orang.

Pada waktu sibuk pukul 08.00 - 12.00, jumlah nasabah rata-rata yang terdapat dalam sistem (Ls) yaitu yang antri dan yang sedang dilayani dengan 6 Teller adalah 104 orang, kalau Teller ditambah menjadi 7, jumlah nasabah dalam sistem berkurang menjadi 9 orang dan kalau teller ditambah menjadi 8, jumlah nasabah dalam sistem berkurang menjadi 7 orang. Pada waktu tidak sibuk, jumlah nasabah rata-rata yang terdapat dalam sistem (Ls) yaitu yang antri dan yang sedang dilayani dengan 6 Teller adalah 16 orang, kalau Teller ditambah menjadi 7, jumlah nasabah dalam sistem berkurang menjadi 8 orang dan kalau teller ditambah menjadi 8 , jumlah nasabah dalam sistem berkurang menjadi 6 orang.

Tabel 8. Nilai Po, Lq, Ls, Pukul 12.00 - 16.00 WIB

\begin{tabular}{|l|l|l|l|l|l|l|}
\hline Keterangan & \multicolumn{3}{|c|}{ Waktu Sibuk } & \multicolumn{3}{c|}{ Waktu Tidak Sibuk } \\
\cline { 2 - 7 } & $\mathrm{T}=6$ & $\mathrm{~T}=7$ & $\mathrm{~T}=8$ & $\mathrm{~T}=6$ & $\mathrm{~T}=7$ & $\mathrm{~T}=8$ \\
\hline $\begin{array}{l}\text { Probabilitas tidak ada } \\
\text { nasabah (Po) }\end{array}$ & 0,00053 & 0,00211 & 0,00266 & 0,00408 & 0,00555 & 0,00606 \\
\hline $\begin{array}{l}\text { Jumlah nasabah dalam } \\
\text { antrian(Lq) }\end{array}$ & 28 & 3 & 1 & 3 & 1 & 1 \\
\hline $\begin{array}{l}\text { Jumlah nasabah dalam } \\
\text { sistem (Ls) }\end{array}$ & 34 & 9 & 7 & 9 & 6 & 6 \\
\hline
\end{tabular}

Sumber: Hasil pengolahan data dari Bank BNI Cabang USU 
Keterangan: Waktu sibuk (tgl 27 - 31 Oktober , $\operatorname{tgl} 1$, 2, 3, 4, 7, 11, 18 November 2011), waktu tidak sibuk (tgl 24-26 Oktober, tgl 8, 9, 10, 14, 15, 16, 17 November 2011).

Dari Tabel 8 dapat dilihat bahwa dari pengamatan pada waktu sibuk pukul 12.00-16.00, dengan memperkerjakan 6 teller seperti selama ini dilakukan Bank BNI Cabang USU, diperoleh $\mathrm{Po}=0,00053$, dengan 7 teller $\mathrm{Po}=0,00211$, dengan 8 teller $\mathrm{Po}=0,00266$. Artinya, dengan 6 orang teller, probabilitas tidak ada nasabah baik dalam antrian maupun yang sedang dilayani adalah $0,053 \%$, dengan 7 orang teller naik menjadi $0,211 \%$ dan dengan 8 orang teller naik menjadi $0,266 \%$.

Pada waktu tidak sibuk pukul 12.00 - 16.00, dengan mempekerjakan 6 teller diperoleh $\mathrm{Po}_{\mathrm{o}}=0,00408$, dengan 7 teller $\mathrm{Po}_{\mathrm{o}}=0,00555$ dan dengan 8 teller $\mathrm{Po}_{\mathrm{o}}$ 0,006406 Artinya, dengan 6 teller probabilitas tidak ada nasabah baik dalam antrian maupun yang sedang dilayani adalah $0,408 \%$, dengan 7 orang teller naik menjadi $0,555 \%$ dan dengan 8 orang teller naik menjadi $0,606 \%$.

Dari Tabel 8 juga dapat dilihat rata-rata banyaknya nasabah yang terdapat dalam baris antrian (Lq) pada waktu sibuk dengan 6 Teller pada pukul 12.00 - 16.00 adalah 28 orang, sedangkan kalau Teller ditambah menjadi 7 orang, rata-rata baris antrian hanya 3 orang dan kalau Teller ditambah menjadi 8 orang, rata-rata nasabah yang menunggu dalam antrian hanya 1 orang. Pada waktu tidak sibuk pukul 12.00 - 16.00 rata-rata banyaknya nasabah yang terdapat dalam baris antrian (Lq) dengan 6 Teller adalah 3 orang, sedangkan kalau Teller ditambah menjadi 7 orang, rata-rata baris antrian hanya 1 orang dan kalau Teller ditambah menjadi 8 orang, rata-rata nasabah yang menunggu dalam antrian hanya 1 orang.

Pada waktu sibuk, pukul 08.00 - 12.00,jumlah nasabah rata-rata yang terdapat dalam sistem (Ls) yaitu yang antri dan yang sedang dilayani dengan 6 Teller adalah 104 orang, kalau Teller ditambah menjadi 7, jumlah nasabah dalam sistem berkurang menjadi 9 orang dan kalau teller ditambah menjadi 8, jumlah nasabah dalam sistem berkurang menjadi 7 orang. Pada waktu tidak sibuk, pukul 12.00 - 16.00, jumlah nasabah rata-rata yang terdapat dalam sistem (Ls) yaitu yang antri dan yang sedang dilayani dengan 6 Teller adalah 9 orang, kalau Teller ditambah menjadi 7 , jumlah nasabah dalam sistem berkurang menjadi 6 orang dan kalau teller ditambah menjadi 8, jumlah nasabah dalam sistem 6 orang.

Berikut ini akan ditunjukkan / diuraikan rata-rata lamanya waktu menunggu dalam antrian (Wq) dan rata-rata lamanya waktu menunggu dalam sistem yaitu waktu menunggu dan untuk mendapatkan pelayanan hingga selesai (Ws) berdasarkan hasil pengolaha data dengan menggunakan Metode Waiting Lines. Dengan hasil perhitungan ini selanjutnya dapat kita bandingkan kedua waktu tersebut (Wq dan Ws) dengan waktu yang dianggap nasabah sebagai waktu yang layak.

Tabel 9. Rata-rata waktu pelayanan dari pukul 08.00 - 12.00 (dalam menit)

\begin{tabular}{|l|l|l|l|l|l|l|}
\hline \multirow{2}{*}{$\begin{array}{l}\text { Jumlah } \\
\text { Teller }\end{array}$} & \multicolumn{3}{|c|}{ Waktu Sibuk } & \multicolumn{3}{c|}{ Waktu Tidak Sibuk } \\
\cline { 2 - 7 } & $\begin{array}{l}\text { Waktu } \\
\text { Menunggu }\end{array}$ & $\begin{array}{l}\text { Waktu } \\
\text { Dilayani }\end{array}$ & $\begin{array}{l}\text { Total } \\
\text { Waktu }\end{array}$ & $\begin{array}{l}\text { Waktu } \\
\text { Menunggu }\end{array}$ & $\begin{array}{l}\text { Waktu } \\
\text { Dilayani }\end{array}$ & Total Waktu \\
\hline 6 orang & 58,38 & 3,53 & 62,31 & 7,32 & 4,15 & 11,47 \\
\hline 7 orang & 2,38 & 3,53 & 6,31 & 1,24 & 4,15 & 5,39 \\
\hline 8 orang & 0,59 & 3,53 & 4,12 & 0,41 & 4,15 & 4,51 \\
\hline
\end{tabular}

Sumber: Hasil pengolahan data dari Bank BNI Cabang USU

Berdasarkan data pada tabel 9, dengan menggunakan 6 teller pada pukul $08.00-12.00$, rata-rata waktu tunggu nasabah pada saat sibuk adalah 58,38 menit dan rata-rata waktu total yaitu untuk menunggu hingga mendapatkan pelayanan adalah 62,31 menit. Apabila dibandingkan dengan waktu tunggu yang diharapkan nasabah berdasarkan wawancara yang 
dilakukan yaitu 5 - 15 menit, waktu menunggu tersebut jauh lebih lama. Demikian juga halnya apabila dibandingkan dengan stadar waktu tunggu yang ditetapkan Bank BNI yaitu 15 menit yang secara kebetulan sama dengan waktu harapan nasabah, belum sesuai dengan prakteknya di lapangan. Apabila teller ditambah menjadi 7 atau 8, rata-rata waktu tunggu nasabah adalah 0,59 - 2,38 menit dan rata-rata waktu total yaitu untuk menunggu hingga mendapatkan pelayanan adalah antara 4,12 - 6,31 menit, di mana waktu tunggu dan waktu total ini masih berada dalam batas toleransi yang diharapkan nasabah maupun waktu standar yang ditetapkan pihak bank.

Pada waktu tidak sibuk, rata-rata waktu tunggu nasabah dengan 6 teller sampai 8 teller berkisar antara 0,41 - 7,23 menit, dan waktu total yaitu menunggu hingga mendapat pelayanan berkisar antara 4,51 - 11,47 menit. Waktu tunggu ini sesuai dengan harapan nasabah (5 - 15 menit) dan juga waktu tunggu standar yang ditetapkan pihak Bank BNI.

Tabel 10. Rata-rata waktu pelayanan dari pukul 12.00 - 16.00 (dalam menit)

\begin{tabular}{|l|l|l|l|l|l|l|}
\hline \multirow{2}{*}{$\begin{array}{l}\text { Jumlah } \\
\text { Teller }\end{array}$} & \multicolumn{3}{|c|}{ Waktu Sibuk } & \multicolumn{3}{c|}{ Waktu Tidak Sibuk } \\
\cline { 2 - 7 } & $\begin{array}{l}\text { Waktu } \\
\text { Menunggu }\end{array}$ & $\begin{array}{l}\text { Waktu } \\
\text { Dilayani }\end{array}$ & $\begin{array}{l}\text { Total } \\
\text { Waktu }\end{array}$ & $\begin{array}{l}\text { Waktu } \\
\text { Menunggu }\end{array}$ & $\begin{array}{l}\text { Waktu } \\
\text { Dilayani }\end{array}$ & Total Waktu \\
\hline 6 orang & 18,30 & 4,15 & 22,45 & 2,44 & 4,15 & 6,59 \\
\hline 7 orang & 2,14 & 4,15 & 6,29 & 1,06 & 4,15 & 5,21 \\
\hline 8 orang & 0,54 & 4,15 & 5,09 & 0,23 & 4,15 & 4,38 \\
\hline
\end{tabular}

Sumber: Hasil pengolahan data dari Bank BNI Cabang USU

Untuk periode pukul 12.00-16.00, dengan menggunakan 6 teller rata-rata waktu tunggu nasabah pada saat sibuk adalah 18,30 menit dan rata-rata waktu total yaitu untuk menunggu hingga mendapatkan pelayanan adalah 22,45 menit. Apabila dibandingkan dengan waktu tunggu yang diharapkan nasabah berdasarkan diwawancara yang dilakukan yaitu 5 - 15 menit, waktu menunggu tersebut masih di luar harapan nasabah dan juga di luar waktu tunggu standar yang ditetapkan Bank BNI yang secara kebetulan sama dengan waktu yang diharapkan nasabah yaitu 15 menit. Apabila teller ditambah menjadi 7 atau 8, rata-rata waktu tunggu nasabah adalah 0,54 - 2,14 menit dan rata-rata waktu total yaitu untuk menunggu hingga mendapatkan pelayanan adalah antara 5,09 - 6,29 menit, di mana waktu tunggu dan waktu total ini masih berada dalam batas toleransi yang diharapkan nasabah maupun waktu standar yang ditetapkan pihak bank.

Pada waktu tidak sibuk, rata-rata waktu tunggu nasabah dengan 6 teller sampai 8 teller berkisar antara 0,23 - 2,44 menit, dan waktu total yaitu menunggu hingga mendapat pelayanan berkisar antara 4,38 - 6,59 menit. Waktu tunggu ini sesuai dengan harapan nasabah (5 - 15 menit) dan juga waktu tunggu standar yang ditetapkan pihak Bank BNI.

Berdasarkan hasil perhitungan yang telah dilakukan dengan menggunakan teori antrian dan hasil pengolahan data dengan menggunakan peragkat lunak computer Waiting Lines, dapat dikatakan bahwa karakteristik sistem antrian nasabah pada Bank BNI Cabang USU dengan menggunakan 6 teller baik pada waktu sibuk maupun waktu tidak sibuk pukul $08.00-12.00$ masih belum optimal. Hal ini dapat dilihat dari perbandingan waktu tunggu nasabah berdasarkan pengolahan data antrian selama satu bulan dengan waktu tunggu harapan atau waktu tunggu yang dapat ditolerir nasabah dan juga standar waktu tunggu yang ditetapkan pihak bank BNI. Waktu tunggu berdasarkan data jauh lebih lama yaitu 58,38 menit pada waktu sibuk pukul 08.00 - 12.00 dan pada waktu tidak sibuk untuk periode waktu yang sama mencpai 18,30 menit.

Hal ini sejalan dengan tingkat kesibukan teller pada waktu sibuk pukul $08.00-12.00$ dengan $\rho=0,99$ dan $\rho=0,93$ pada waktu tidak sibuk pukul $08.00-12.00$. Tingkat kesibukan 
teller yang sangat tinggi ini dimana mereka sibuk hampir sepanjang jam kerjanya dapat mengakibatkan pelayanan kurang optimal karena teller terlalu lelah yang dapat mengakibatkan nasabah tidak puas. Dampak selanjutnya dari ketidakpuasan nasabah adalah bank kemungkinan akan kehilangan sebagian pelanggan yang sudah dimiliki sebelumnya. Oleh sebab itu, pihak bank harus mencari solusi untuk memperbaiki karakteristik sistem antrian nasabahnya, antara lain dengan menambah jumlah teller pada jam-jam tertentu dimana kesibukan cukup tinggi dan pada tingkat kesibukan yang tidak terlalu tinggi sebagian teller dapat ditugaskan untuk melakukan pekerjaan lain diluar melayani nasabah.

Kesibukan teller yang terlalu tinggi dapat juga menimbulkan kesulitan dalam melaksanakan tugas-tugas di luar pelayanan, misalnya memeriksa kebenaran tanda tangan nasabah, asli tidaknya uang yang masuk, mengecek sisa kas teller selama jam kerja dan tugastugas teller lainnya. Dimana semuanya hal ini berpengaruh terhadap kepuasan nasabah walaupun secara tidak langsung.

Dengan melihat situasi antrian di atas dibandingkan dengan jumlah teller sebanyak enam (6) orang dapat disimpulkan bahwa pelayanan belum sesuai harapan nasabah pada saat sibuk periode pukul 08.00 - 12.00 dan periode 12.00 - 16.00. Pada saat sibuk pukul 08.00 12.00, tingkat kesibukan teller $(\rho)=99 \%$, dengan rata-rata waktu tunggu $(\mathrm{Wq})=58,38$ menit, waktu total $(\mathrm{Ws})=62,31$ menit dan probabilitas waktu luang teller $(\mathrm{Po})=0,016 \%$. Demikian juga halnya pada pukul $12.00-16.00$, tingkat kesibukan teller $(\rho)=97 \%$, dengan rata-rata waktu tunggu $(\mathrm{Wq})=18,30$ menit, waktu total $(\mathrm{Ws})=22,05$ menit dan probabilitas waktu luang teller $(\mathrm{Po})=0,22 \%$. Dimana waktu tersebut masih lebih lama dibanding waktu yang ditoleransi nasabah dan waktu standar yang ditetapkan Bank BNI Cabang USU. Maka baik pada pukul 08.00 - 12.00 maupun pukul 12.00 - 16.00 saat sibuk sebaiknya jumlah teller perlu ditambah menjadi 7 orang sehingga pelayana terhadap nasabah dapat ditingkatkan. Apabila jumlah teller menjadi 7 orang, nasabah tidak perlu menunggu terlalu lama untuk mendapatkan pelayanan. Karena rata-rata waktu menunggu sudah berada dalam batas toleransi yaitu 5 - 15 menit.

Penambahan teller menjadi 7 orang pada saat sibuk tidak dapat dilakukan begitu saja atau tidak cukup hanya dilihat dari segi peningkatan kepuasan nasabah, tetapi harus dilihat dari bahan te sisi pihak Bank BNI Cabang USU. Penambahan satu orang teller akan menambah biaya bagi bank yaitu berupa gaji untuk teller tambahan tersebut. Harus dibadingkan antara peningktan pelayanan yang diterima nasabah dengan besarnya manfaat yang diterima bank sebagai dampak perbaikan pelayanan tersebut. Salah satu cara mengatasinya adalah bahwa kasir hanya perlu ditambah pada saat sibuk, sementara pada saat tidak sibuk sebagian teller dapat dialihka untuk melaksanakan tugas-tugas lain diluar pelayanan terhadap nasabah sehingga waktu menganggur teller dapat diminimalkan.

Pada saat tidak sibuk periode waktu yang sama, tingkat kesibukan teller $(\rho)$ adalah antara 0,84 - 0,93, dengan rata-rata waktu tunggu (Wq) antara 2,44 - 7,32 menit, waktu total (Ws) antara 6,59 - 11,47 menit dan probabilitas waktu luang teller (Po) antara 0,14 - 0,40\%. Dengan demikian pada saat tidak sibuk tidak ada masalah dalam sistem antrian karena waktu tunggu masih dalam batas toleransi dan jumlah teller sebanyak 6 orang dapat dipertahankan.

\section{Kesimpulan:}

\section{KESIMPULAN DAN SARAN}

1. Bank BNI mempekerjakan 6 (enam) teller untuk melayani nasabah setiap hari.

2. Pelayanan yang dilakukan Bank BNI dengan 6 (enam) teller pada waktu sibuk belum optimal dengan rata-rata waktu tunggu nasabah antara 18,30 menit - 58,38 menit, sementara 
waktu tunggu yang dapat ditolerir nasabah adalah 15 menit dan waktu tunggu standar yang ditetapkan Bank BNI Cabang USU adalah 15 menit.

3. Pada waktu tidak sibuk dengan 6 (enam) teller, rata-rata waktu tunggu nasabah pada pukul 08.00 - 12.00 dan pukul 12.00 - 16.00 antara 2,44 menit - 7,32 menit. Waktu tunggu tersebut masih berada dalam batas waktu yang dapat ditoleransi nasabah maupun waktu tunggu standar yang ditetapkan pihak bank. Hal itu berarti bahwa jumlah teller sebanyak 6 (enam) orang dapat dipertahankan.

\section{Saran}

Pada waktu sibuk, baik pukul 08.00 - 12.00 maupun pukul 12.00 - 16.00, jumlah teller sebaiknya ditambah menjadi 7 (tujuh) orang supaya pelayanan yang dilakukan Bank BNI Cabang USU sesuai harapan nasabah, yaitu waktu tunggu rata-rata berkisar antara 5 menit - 15 menit.

\section{DAFTAR PUSTAKA}

Barry, Render dan Jay Heizer. Manajemen Operasi : Terjemahan oled Dwianoegraha Setyoningsih dan Indra Almahdy dari Operation Management. Jakarta : Salemba Empat, 2004

Handoko, T. Hani. Dasar-Dasar Manajemen Produksi dan Operasi. Yogyakarta : BPFE, 1995

Levin, Richard I. Pengambilan Keputusan Secara Kuantitatif : Terjemahan oleh Nartanto dari Quantitative Approaches to Management. Jakarta : PT Granfindo Persada, 1993

Schroeder, Roger G. Manajemen Operasi, jilid 1. Terjemahan oleh tim penerjemah Erlangga Jakarta: Erlangga, 1997.

Sugiyono, dr. Metode Penelitian Administrasi. Bandung : CV Alfabeta, 2001

Taylor, Bernard W III. Sains Manajemen : Terjemahan oleh : Vita Silvira dari Introduction to Management Science. Jakarta : Salemba Empat, 2005. 